\title{
Endocrine Disruptors in Food Chain
}

\author{
Eram S. Rao*, C. Lalmuanpuia, Rizwana, Utkarsh Singh and Divyanshu Prajapat \\ Department of Food Technology, Bhaskaracharya College of Applied Sciences, \\ University of Delhi, India \\ *Corresponding author
}

\section{A B S T R A C T}

\begin{tabular}{|c|}
\hline $\begin{array}{l}\text { Ke y w or d s } \\
\text { endocrine } \\
\text { disruptors, } \\
\text { phytoestrogens, } \\
\text { endocrine } \\
\text { disrupting } \\
\text { chemicals }\end{array}$ \\
\hline Article Info \\
\hline $\begin{array}{l}\text { Accepted: } \\
\text { 12 May } 2021 \\
\text { Available Online: } \\
\text { 10 June } 2021\end{array}$ \\
\hline
\end{tabular}

Endocrine Disruptors (ED) are substances that impede the normal performance of the endocrine system. It leads to several adverse effects on health such as abnormalities of the reproductive, skeletal, immune, metabolic, neurological, cardiovascular system as well as several types of carcinomas. These could be either naturally occurring organic substances such as phytoestrogens or artificially synthesised chemicals employed in the manufacture of plastics, plasticizers, pesticides, synthetic hormones, pharma compounds etc. They are found to routinely find their way in the human food chain through different pathways such as from air, water, agricultural produce, animal foods, drugs etc and are a health hazard. This paper traces the history, sources as well as the adverse health effects of endocrine disruptors on health.

\section{Introduction}

The endocrine system of the humans is responsible for the performance of several important physiological functions in the body by secreting hormones through its ductless glands. The Endocrine Disrupting Chemicals (EDCs) may prevent the production, secretion, transportation, uptake or breakdown of these hormones which are chemical messengers responsible for endocrine homeostasis. Darbre (2019) reported that even low levels of exposure may promote disrupting effects, particularly if it takes place in the critical development period. ED can interfere with metabolic pathways leading to several adverse effects on health such as abnormalities of the reproductive, skeletal, immune, metabolic, neurological, cardiovascular system as well as several types of carcinomas and thyroid and adrenal dysfunction. Therefore, ED are a serious cause of public health concern for the present century. According to the recent investigations by Kasonga et al., (2020) they are perceived as a major risk not only to the human health but also of the wildlife and the 
aquatic fauna and flora. The endocrine disrupting functions are also present in some naturally occurring organic compounds such phytoestrogens and mycoestrogens. However, the vast majority occurs in inorganic compounds such as during the synthesis of hormones, chemicals such as polymers used for making plastics, packaging materials, plasticizers, pesticides, solvents, pharma compounds, personal care products etc. They find their way in the human food chain through different pathways such as air, water, soil, cosmetics and drugs and pose a health hazard. Lauretta et al., (2019) have reported presence of ED in highest concentrations in humans as they are fat soluble and tend to bioaccumulate and bio magnify easily.

\section{History of EDC's}

It was McBride (1961) who first reported the adverse effects of endocrine disruption in pregnant women when they were administered a drug named thalidomide to alleviate nausea. These women gave birth to babies with congenital deformities. Severe ill effects due to accidental exposure to a persistent organic pollutant Dioxin (EDC) has been reported in literature in Italy in 1976. It resulted in decrease in fertility of both the genders along with enhanced risk of malignancies and CVD's (Eskenazi et al., 2018).

Similarly, Hoover et al., (2011) have reported abnormalities of the reproductive system including carcinomas when Diethylstilbestrol (DES), a hormone which simulates estrogen like activity in pregnant women was prescribed to pregnant women to prevent complications during gestation. McLachlan (2001) have confirmed similar abnormalities associated with reproductive health due to exposure to EDC's in many wildlife species too. Human beings are constantly exposed to EDC's like pesticides and other chemicals which are routinely used for agricultural practices. They are an occupational hazard not only for the farmers but also to the inhabitants of the nearby colonies and is a health hazard to the consumers and the forthcoming generations. In 2013 in India, due to gross negligence of school authorities children were served meals cooked in oil contaminated with an organophosphate pesticide. Twenty-three children lost their lives and forty-eight were hospitalised due to severe chemical poisoning (Idrovo 2014).

The World Health Organization (WHO) and the United Nations Environment Programme (UNEP) released a comprehensive report on EDCs in 2013 suggesting for more research to have a better understanding of their risks to human and animal health (Bergman et al., 2013).

\section{Endocrine Disruptors in the Food Chain}

Food which finally reaches the plate of the consumer encompasses a journey from farm to fork using an array of chemicals. These are employed right from growing, harvesting, processing, preserving, packaging, transporting to storing them (Rao et al., 2021). At every stage of this food chain there is a likelihood of an EDC entering the human system through the food consumed without being detected. Water is also an important source of ED which is used extensively for cleaning and processing of foods in the industry. Polymers/ plastics are chemicals which are used in the manufacture of food packaging materials and are implicated in contaminating the food with endocrine disruptors.

\section{Plant food sources of ED}

\section{Phytoestrogens}

Phytoestrogens are compounds which naturally occur in plants. Soybeans, tempeh, 
clover, flaxseeds, mung beans, carrots, sesame seeds, oats, barley etc. are some of the known sources of phytoestrogens in diet. These foods contain oestrogen, a hormone known to provide relief to women from perimenopausal symptoms, may prevent bone loss and reduce risk of osteoporosis. Some studies have reported that it may reduce the risk of cancer, cardiovascular disease, obesity, metabolic syndrome and type-2 diabetes too. However, Rietjens et al., (2017) on the contrary have reported of (anti) estrogenic properties of phytoestrogens and have raised concerns of them possibly acting as endocrine disruptors. In vitro, they exert their estrogenic activity by interacting with estrogen receptors or may also act as anti-estrogens. Thus, in theory, phytoestrogens and structurally related compounds could harm the reproductive health of humans by acting as anti-estrogens. Regular consumption of plant-based diets in the form of cereals, pulses, nuts and oilseeds along with fruit and vegetables could expose the individuals to phytoestrogens. Phytoestrogens includes more than 100 molecules, all of which are polyphenols and can be divided into four major groups: isoflavones, prenylflavonoids, coumestans and lignans.

\section{Isoflavones}

Isoflavones are a subclass of flavonoids, they are the major phytoestrogens naturally found in plants. Their sources include soy-based foods, legumes, pulses, red clover and beans. Isoflavones include compounds like genistein, daidzein, glycitein, formononetin and biochanin A. These are mainly found in their conjugated forms like genistin, daidzin, puerarin, glycitin, ononin and sissotrin. Compounds like isoflavonoids, equol, daidzein, and coumestrol found in soy products are capable of binding with estrogen receptors. Genistein present in soy milk, soy cheese is a specific inhibitor of tyrosine protein kinases (Pilšáková et al.,2010).

\section{Prenylflavonoids}

Prenylated flavonoids combine the flavonoid moiety and the lipophilic prenyl side-chain. A great number of derivatives belonging to the class of chalcones, flavones, flavanones, isoflavones and other complex structures possessing different prenylation patterns have been studied for their potential as antioxidant agents. (Clementina \& Artur, 2020). Major prenylflavonoids includes prenylnaringenin, and isoxanthohumol. They are found in hops and beer. 8- prenylnaringenin is reported to be the most potent phytoestrogen among prenylflavonoids (Stevens \& Page, 2004).

\section{Coumestans}

Food sources include Leguminosae family such as peas, beans, alfalfa and clover sprouts. Coumestans are compounds derived from coumarin and includes compounds like coumestrol, 4'- methoxycoumestrol, repensol and trifoliol (Albini et al., 2014).

\section{Lignans}

Lignans that are categorised as phytoestrogens are enterodiol and enterolactone. These are non-flavanoid phytosterols formed from lignan precursors. Lignan precursors include pinoresinol, podophyllotixin and stegnacin which are present in linseed (flax) and til (sesame). Secoisolariciresinol is present in flaxseed. de Kleijn et al., (2002) and Valsta et al., (2003) have reported that broccoli and cabbage are some of the vegetables rich in lignans. Vinyl-2-thiazolidine (goitrine) is found in cabbage, mustard, rapeseed, etc. naturally which when consumed by milching animals can lead to exposure of the humans too. Lignans can even be transferred to the offspring via the milk.

Apart from phytoestrogens, raw fruits and 
vegetables may also contain EDs in the form of pesticide residues on their surfaces. Pesticides like DDT can cause breast cancer and other complications. Maneb is a goitrogenic pesticide that can alter thyroid functioning (Cos P et al., 2003).

\section{Animal food sources of EDs}

Unintentional contaminants such as heavy metals and endocrine disruptors can find their way in the human food chain through air, water, food, feed, drugs, antimicrobial residues and pharmaceuticals. Schantz \& Widholm (2001) have reported exposure to several of them such as phthalates, alkyl phenolic compounds, polychlorinated biphenyls and polychlorinated dibenzodioxins, organochlorine pesticides, bisphenol $\mathrm{A}$, and metals including lead, mercury, and cadmium.

The non-vegetarian population are at higher risk for exposure to these endocrine disrupting chemicals due to their lipid-solubility. These tend to accumulate in the adipose tissues of the animal and lead to bioaccumulation. This problem is further intensified by the process of biomagnification, in which concentrations of EDs increase at higher trophic levels. Ross et al., (2000) and Ikonomou et al., (2002) have reported of biomagnification in numerous species of marine mammals.

The concentrations of EDs are reported to be 100 times greater in the body of aquatic birds than in the surrounding water due to biomagnification (Anderson \& Hickey 1976; Norstrom et al., 1976).

Hormones such as testosterone propionate, trenbolone acetate, estradiol, zeranol, progesterone, melengestrol acetate, and bovine somatotropin are often injected in the bodies of farm animals. This is to attain either increase milk production or rapid muscle growth in the livestock. Nachman \& Smith (2015) have reported that consumption of meat or dairy products of such animals may increase the risk of diseases such as breast cancer in humans. This is due to the presence of metabolically active metabolites or residues of such drugs that get stored in the adipose tissues of the animals or are secreted in the milk of these animals and consumed by humans.

\section{Fungal sources}

Aflatoxin B1 is a mycotoxin produced by fungi Aspergillus flavus and Aspergillus parasiticus. It is known to infest food products like peanuts, maize etc during post-harvest storage. When cows graze on fodder or vegetation infested by the fungi, toxin is secreted in the milk which enters the food supply chain when such a milk is milched and stored (Storwik et al., 2011). The toxin when consumed may cause cancer in humans and can adversely affect the endocrine system of a pregnant woman.

Mycoestrogen known as Zearalenone (ZEA) can be produced by various species of Fusarium like $F$. roseum, $F$. tricinctum, $F$. sporotrichioides, $F$. oxysporum and $F$. moniliforme. Maize and hay when stored in warm and humid conditions might get infested by the fungi due to which high concentration of Zearalenone is produced in them. ZEA and its metabolites like zearalenol (ZOL) have shown estrogenicity by binding with oestrogen receptors in farm animals like pigs affecting the oestrogen dependent organs causing alteration in vaginal growth and pseudopregnancy. ZEA and its metabolites are linked with reproductive problems in males and females like precocious puberty in teenagers affecting body growth, brain growth and maturation of gonads. Some other mycotoxins like trichothecenes and fumonisins are produced by Fusarium that can interact with ZEA causing health issues (Metzler et al., 2010). 


\section{Water sources}

The pollution of aquatic ecosystems with EDs has recently caused a serious public health concern. The sources of EDs that contaminate the water bodies include municipal and industrial wastewaters, agriculture inputs, pharmaceutical and personal care products from hospital wastes. Stasinakis et al., (2010) have studied various natural and synthetic chemicals and have identified the most potent EDs which are present in the effluents. These include natural steroids (estrone (E1), steroid estrogens, such as $17 \beta$-estradiol (E2) and estriol (E3)) and synthetic chemicals such as bisphenol A (BPA), alkylphenols and 4nonylphenol (NP).

Although there are many chemicals which are released in the waste water that are potential EDs, most work reported to date has focused on xenobiotic estrogens of the alkylphenol group and steroid estrogens, since these two groups of chemicals have demonstrated estrogenic effects in fish.

\section{EDs from packaged foods}

Food packaging materials such as glass, paper, polymers etc are manufactured using chemicals, which if ingested, could be hazardous to the humans. Polymers or plastics are almost ubiquitous in packaging of foods. These packaging materials are manufactured using chemicals which are known to be endocrine disrupting chemicals (EDCs) in humans. These include bisphenol A (BPA), styrene and phthalates like di-ethylhexyl phthalate (DEHP), di-butyl phthalate (DBP), benzyl butyl phthalate (BBP), di-isononyl phthalate (DINP), di-isodecyl phthalate (DIDP), and di-n-octyl phthalate (DnOP) (Bang et al., 2012).

BPA is the main constituent of polycarbonate plastic and is commonly used for packaging of foods and beverages that can cause neural and reproductive disorders. Charles et al., (2012) have studied the effect of hidden plastic, which is not directly noticed by the consumers such as on bottle caps, used in printing inks, lining of cans, laminates like tetra packs.

This can migrate into the food matrix during processing of foods before consumption like heating of can or a retort pouch. BPA along with epoxy resins are used for packaging of baby foods and coating of cans. Several factors such as time and temperature of storage of food, contact with different types of plastic, heat for sterilization, contact surface, plastic material (baby bottles), type of food and packaging temperatures causes leaching of plasticizers into the food. The newborn are exposed to these synthetic chemicals causing reduced body weight and compromised body growth (García-Córcoles et al., 2018).

\section{Adverse Health effects of Endocrine Disruptors}

The widespread use of endocrine disruptors in the food chain have led to an incremental deterioration of global health and sharp increase in obesity and metabolic diseases in the population. Papalou et al., (2019) have studied the mechanism with which EDCs affect hormones and promote metabolic disease in humans. They have suggested strong pathways supported with data by way of experimental inputs using animal models in order to understand the mode of action and have called for instant action for policymakers.

\section{Metabolic Disorders}

\section{Obesity}

Obesogens are endocrine disrupting chemicals that can cause disturbance of endocrine system. Rotondo \& Chiarelli, (2020) have reported that the EDs are responsible for the decrease in the basal metabolism rate as well 
as interferes with regulation of appetite and satiety, both in humans as well as in cellular and animal models.

They disrupt the energy homeostasis of the body leading to obesity and endocrine regulation of adipose tissue, leading to the production of adipocytokine, enlargement and multiplication of adipocytes.

\section{Type II Diabetes Mellitus}

Disruption of the endocrine system leads to hormonal imbalance, which may influence the development and pathogenesis of metabolic disorders, particularly type 2 diabetes mellitus (Priyam et al., 2018).

Endocrine disruptors include diabetogens such as dioxins, PCBs, organochloride pesticides, BPA, which may disturb insulin sensitivity in peripheral tissues or can impair insulin production in the beta cells of pancreas causing diabetes.

Rotondo \& Chiarelli, (2020) have suggested that TBT (Tributyltin chloride) may cause reduction of $\beta$ cell and $\beta$ cell apoptosis; phthalates cause reduction of $\beta$ cell insulin; and BPA cause stimulation of glucose-induced insulin secretion in human islets of Langerhans.

Engineered nanomaterials find innovative applications in various industries but can have a detrimental impact on human health due to its toxicological concerns.

Titanium oxide nanoparticles (TiO2-NPs) and chromium nanoparticles (CrNano) affect insulin resistance in liver-derived cells causing increased production of insulin like molecules that cause reduced insulin sensitivity and devour the pathway. (Priyam et al., 2018)

\section{Cancer}

Meeker \& Ferguson, (2012) have reported that phthalates found in plastics, medical applications, personal care products, home furnishings etc. are known to cause testicular and prostate cancer. Similarly, DDT (1,1,1trichloro-2,2-bis (4-chlorophenyl) ethane) which is a persistent insecticide used for pest control in malaria management in some countries (Purnomo, et al., 2011) is associated with the risk of breast cancer (Soto \& Sonnenschein, 2015). According to E. Cubo et al., (2004) dioxins, found almost universally in the environment and food chain, which accumulate in the fatty tissue of animals, can also cause cancer. Bisphenol A (BPA), a manmade chemical substance that is used for producing many plastic wares, is carcinogenic (Irshad et al., 2020).

\section{Neurological Disorders}

Polychlorinated biphenyls are one of the most studied endocrine-disrupting chemicals (EDCs) for their neurobehavioral effects, especially on neurodevelopment and cognitive performance. Moreover, PCBs may reduce the motivation for social behaviours and cause depressive-like symptoms through overall reductions in dopaminergic and glutamatergic functions in the limbic system (Bell, 2014).

\section{Reproductive Disorders \& Developmental disorder}

EDCs have shown to have adverse effects on normal development of reproductive organs and functions of not only human beings but also of wildlife and experimental animals. In females, the chemical exposures may interfere with reproductive behaviour and cause infertility, pregnancy loss, growth retardation, intrauterine foetal demise, birth defect, and ovarian failure (L Brevini et al., 2005). 
Table.1 Classification of phytoestrogens (Albini et al., 2014)

\begin{tabular}{|c|c|c|}
\hline Class & Chemical compounds & Plantsources \\
\hline Coumestans & $\begin{array}{c}\text { Coumestrol, Wedelolactone } \\
\text { and Plicadin } \\
\text { Genistein, Diadzein, } \\
\text { Glycetein and } \\
\text { Formononetin }\end{array}$ & Clover, alfaalfa, split peas, pinto beans \\
\hline Isoflavones & $\begin{array}{c}\text { Pinoresinol, } \\
\text { Podophyllotixin and } \\
\text { Enterodiol }\end{array}$ & $\begin{array}{c}\text { Flax seed, sesame, soybeans, crouciferous } \\
\text { vegetables, apricot, strawberries }\end{array}$ \\
\hline Lignans & $\begin{array}{c}\text { Prenylnaringerin and } \\
\text { Isoxanthohumol }\end{array}$ & Hops, beer \\
\hline Prenylflavonoids & & \\
\hline
\end{tabular}

Table.2 Studies on animal exposure to EDs and their harmful effects

\begin{tabular}{|c|c|c|c|}
\hline $\begin{array}{l}\text { Endocrine } \\
\text { Disruptors }\end{array}$ & Effects on animals & Animals & References \\
\hline DDT,DDE & $\begin{array}{l}\text { Shorter AGDs (Anogenital } \\
\text { Distance). } \\
\text { Higher liver mass } \\
\text { Presence of lipid droplets in the } \\
\text { hepatic tissue. } \\
\text { Higher testicular mass. } \\
\text { Apical sloughing. } \\
\text { Reduced seminiferous tubule } \\
\text { diameters. } \\
\text { Disorganization of the } \\
\text { seminiferous epithelium. } \\
\text { Higher total testosterone } \\
\text { concentration. }\end{array}$ & Rats & $\begin{array}{l}\text { Patrick et al., } \\
\quad(2016)\end{array}$ \\
\hline Atrazine & $\begin{array}{l}\text { Increase in abdominal swelling. } \\
\text { Increase in progesterone levels. } \\
\text { Decrease in spawning. } \\
\text { Increase in follicular atresia. } \\
\text { Increase in head width to body } \\
\text { ratio. } \\
\text { Reproductive dysfunction and } \\
\text { molecular alterations in adults } \\
\text { exposed during embryogenesis } \\
\text { and morphological alterations in } \\
\text { their offsprings. }\end{array}$ & Female zebrafish & $\begin{array}{l}\text { Wirbisky et al., } \\
\text { (2016). }\end{array}$ \\
\hline
\end{tabular}




\begin{tabular}{|c|c|c|c|}
\hline $\begin{array}{l}\text { Bisphenol } \mathrm{A} \text { and } \\
\text { raloxifene }\end{array}$ & $\begin{array}{l}\text { Affecting the availability of } \\
\text { transcription coactivator proteins. } \\
\text { Transcription factors for steroid } \\
\text { receptors. } \\
\text { Disruption of brain cytochrome } \\
\text { P450 aromatase. }\end{array}$ & Fish & $\begin{array}{l}\text { Söffker et al., } \\
\text { (2012). }\end{array}$ \\
\hline PCBs & $\begin{array}{l}\text { Reduction in the germ cell } \\
\text { number. } \\
\text { Decrease in the reproductive } \\
\text { organ weights, } \\
\text { Reduced number of implantation } \\
\text { sites. } \\
\text { Embryotoxicity. } \\
\text { Reduced litter size. } \\
\text { Alterations of the menstrual cycle } \\
\text { and increased incidence of } \\
\text { abortions and embryo resorption. }\end{array}$ & $\begin{array}{l}\text { Rodents } \\
\text { Monkeys }\end{array}$ & $\begin{array}{l}\text { Gandolfi et al., } \\
\text { (2002). }\end{array}$ \\
\hline $\begin{array}{l}\text { Vinclozolin, } \\
\text { methoxychlor, } \\
\text { linuron or di-n- } \\
\text { butyl phthalate }\end{array}$ & $\begin{array}{l}\text { delay the onset of androgen- } \\
\text { dependent preputial separation, } \\
\text { reproductive disorder. Serum LH, } \\
\text { testosterone, } 5 \text { a-androstane } \\
\text { and } 3 a, 17 \text { P-diol concentrations } \\
\text { were increased. }\end{array}$ & Male Rats, Rabbits & $\begin{array}{l}\text { Gray et al., } \\
\text { (2001). }\end{array}$ \\
\hline $\begin{array}{l}\text { Methylmercury } \\
\text { Cadmium }\end{array}$ & $\begin{array}{l}\text { Disruption of GABA levels fish } \\
\text { Neuroendocrine control of } \\
\text { reproduction, neurotransmitter } \\
\text { systems } \\
\text { Disrupted calcium currents in } \\
\text { nerve collar neurons. } \\
\text { Inhibition GABA-activated } \\
\text { chloride currents via increased } \\
\text { calcium levels in nerve collar } \\
\text { cells. } \\
\text { Acetylcholinesterase inhibition, }\end{array}$ & $\begin{array}{l}\text { Neovisonvison fish, } \\
\text { Lymnaeapalustris, L. } \\
\text { stagnalis, Procambarus } \\
\text { clarkia. }\end{array}$ & $\begin{array}{c}\text { Waye \& } \\
\text { Trudeau, (2011) }\end{array}$ \\
\hline
\end{tabular}


Table.3 EDCs associated with water and their harmful effects on aquatic life

\begin{tabular}{|c|c|c|c|}
\hline EDCs and their source & Aquatic animal & $\begin{array}{c}\text { Harmful effects on } \\
\text { aquatic life }\end{array}$ & References \\
\hline $\begin{array}{c}\text { Municipal and industrial } \\
\text { wastewaters: } \\
\text { Alkylphenolpolyethoxylates } \\
\text { E-sitosterol, genistein, matairesol, } \\
\text { enterodiol and enterolactone } \\
\text { (phytoestrogens from food } \\
\text { processing) } \\
\text { Xenoestrogens like bisphenol A, } \\
\text { organotin and phthalates (released by } \\
\text { tubes, paintings, plastics) } \\
\text { Heavy metal like mercury, lead, } \\
\text { cadmium }\end{array}$ & $\begin{array}{l}\text { Ramshorn snail } \\
\text { (Marisa } \\
\text { cornuarietis), } \\
\text { Trout, } \\
\text { Common roach } \\
\text { (Rutilusrutilus) }\end{array}$ & $\begin{array}{l}\text { Estrogenic effect, a } \\
\text { reduced reproductive } \\
\text { capacity, Behavioral } \\
\text { changes like vitellogenin } \\
\text { induction, courtship } \\
\text { impairment and } \\
\text { development of ovotestes, } \\
\text { acute toxicity by heavy } \\
\text { metals. }\end{array}$ & $\begin{array}{l}\text { Siegrist et al., } \\
2005\end{array}$ \\
\hline $\begin{array}{c}\text { Agriculture inputs: } \\
\text { Pesticides and herbicides like DDT, } \\
\text { Atrazine, } S \text {-metolachlor, alachlor, } \\
\text { nicosulfuron, cyfluthrin, } \lambda- \\
\text { cyhalothrin, tebupirimphos, } \\
\text { metalaxyl, or propiconazole } \\
\text { - Alkylphenols (surfactants) } \\
\text { Nonylphenol, nonylphenoletoxylate, } \\
\text { octylphenol, octylphenoletoxylate }\end{array}$ & $\begin{array}{l}\text { Amphibian larvae, } \\
\text { Leopard frog (R. } \\
\text { pipiens), African } \\
\text { clawed frog } \\
\text { (Xenopuslaevis) }\end{array}$ & $\begin{array}{l}\text { Acute toxicity, morbidity, } \\
\text { and mortality chemically } \\
\text { castrates and feminizes } \\
\text { exposed male amphibian } \\
\text { larvae, retard growth and } \\
\text { size at metamorphosis, } \\
\text { retards larval } \\
\text { development growth and } \\
\text { thymic damage. }\end{array}$ & $\begin{array}{l}\text { Esplugas et al., } \\
\text { 2007; Hayes et } \\
\text { al., } 2006\end{array}$ \\
\hline $\begin{array}{c}\text { Pharmaceutical products: } \\
\text { ethynylestradiol } \\
\text { diethylstilbestrol } \\
\text { 17-ethinylestradiol }\end{array}$ & $\begin{array}{l}\text { Zebrafish } \\
\text { (Daniorerio), } \\
\text { Roach }\end{array}$ & $\begin{array}{l}\text { Reproductive } \\
\text { impairment. }\end{array}$ & $\begin{array}{l}\text { Nash et al., 2004; } \\
\text { Esplugas et al., } \\
2007\end{array}$ \\
\hline $\begin{array}{c}\text { Personal care products: } \\
\text { - } \quad \text { Parabens (p-hydroxybenzoic } \\
\text { acid esters) like Methyl, ethyl, } \\
\text { propyl and butylparabens } \\
\text { - Phthalates like diethyl } \\
\text { phthalate, dimethyl phthalate, dibutyl } \\
\text { phthalate } \\
\text { - Perfluorinated Chemicals } \\
\text { (PFCs) are water, grease, stain and } \\
\text { dirt repellents } \\
\text { - Aluminium salts, a } \\
\text { - metalloestrogen } \\
\text { Biocides like Triclosan, } \\
\text { triclocarbon in toothpaste, soaps. }\end{array}$ & $\begin{array}{l}\text { Algae, Nektons like } \\
\text { fish, shark, squid } \\
\text { and other marine } \\
\text { animlas e.g., } \\
\text { Coiliagrayi, } \\
\text { Lateolabraxjaponic } \\
\text { us, }\end{array}$ & $\begin{array}{c}\text { Reproductive } \\
\text { impairment, immune } \\
\text { system damage, } \\
\text { population degradation. }\end{array}$ & $\begin{array}{c}\text { Esplugas et al., } \\
\text { 2007; } \\
\text { Nicolopoulou- } \\
\text { Stamati et al., } \\
\text { 2015; Fan et al., } \\
2019\end{array}$ \\
\hline
\end{tabular}


Table.4 Classification of EDCs based on source of food in the supply chain

\begin{tabular}{|c|c|c|}
\hline Source of EDCs & EDCs & References \\
\hline Plants & $\begin{array}{l}\text { Phytoestrogens like isoflavonoids, } \\
\text { equol, daidzein, coumestrol, } \\
\text { genistein, lignan, goitrin, } \\
\text { glycyrrhizic acid, maneb, } \beta \text { - } \\
\text { sitosterol and biochanin A }\end{array}$ & Cos P et al., (2003). \\
\hline Animals & $\begin{array}{c}\text { DDT, its metabolite, DDE, PCBs, } \\
\text { and other residues of } \\
\text { organochlorine, organotins, } \\
\text { dioxins. }\end{array}$ & Colborn et al., (1993). \\
\hline Fungus & $\begin{array}{l}\text { Mycotoxin like Aflatoxin B1, } \\
\text { trichothecenes and fumonisins, } \\
\text { Mycoestrogen like Zearalenone and } \\
\text { its metabolites like zearalenol }\end{array}$ & $\begin{array}{c}\text { Storwik et al., (2011), Metzler } \text { et } \\
\text { al., (2010) }\end{array}$ \\
\hline Water & $\begin{array}{c}\text { Estrogenic EDCs like bisphenol A, } \\
\text { pesticides, nonylphenols, } \\
\text { phthalates. }\end{array}$ & Burkhardt-Holm, (2010) \\
\hline Processed Foods & $\begin{array}{l}\text { AGEs (Advanced glycation end } \\
\text { products) like acrylamide, furan, } \\
\text { CML- NE-carboxymethyl-lysine, } \\
\text { CEL-Ne-1-carboxyethyl-lysine, }\end{array}$ & $\begin{array}{c}\text { Ravichandran et al., (2019), Gill et } \\
\text { al., (2019). }\end{array}$ \\
\hline Packaged Foods & $\begin{array}{l}\text { Bisphenol A (BPA), styrene and } \\
\text { phthalates like di-ethylhexyl } \\
\text { phthalate (DEHP), di-butyl } \\
\text { phthalate (DBP), benzyl butyl } \\
\text { phthalate (BBP), di-isononyl } \\
\text { phthalate (DINP), di-isodecyl } \\
\text { phthalate (DIDP), and di-n-octyl } \\
\text { phthalate (DnOP) }\end{array}$ & Charles et al., (2012). \\
\hline
\end{tabular}

Phthalates can lead to unfavourable reproductive and developmental effects in humans. In males, environmental or occupational exposures to EDCs can cause changed levels of hormones in their bodies causing declined reproductive capacity (Meeker \& Ferguson, 2012). Dioxins can cause reproductive and developmental problems, damage the immune systems, interfere with hormones (E. Cubo et al., 2004). Endocrine disruptors that interfere with estradiol production in the follicles can act as ovulatory disruptors, and while interfering with progesterone production by luteal cells they can act as abortifacients (Gregoraszczuk, 2002). PCBs are associated with changes in reproductive behaviour by disrupting reproductive function by suppressing many aspects of the associated hypothalamic circuitry (Bell, 2014).

The harmful effects of endocrine disruptors have been reported by many investigators with scientific evidence indicating that they are a real threat for human health, wildlife, aquatic biodiversity and ecosystem. Therefore, there is an urgent need for consumer awareness to educate the public, media, food handlers and 
governmental agencies regarding the sources of EDs, their prevention strategies to avoid exposure particularly in young children. Food is the major route of human exposure to EDCs. It is duty of the scientific community and healthcare professionals to play a greater role in spreading awareness about EDCs and their sources. Furthermore, studies are required to understand the mechanism of EDCs, the relationship between dose-effect, the link between the substance and pathology. Phenomena such as bioaccumulation, biomagnification and trans-generational inheritance are clear obstacles to research. There has been enough evidence to suggest the need for much more stringent regulations and attempts to minimize chemicals responsible for endocrine disruption in the food supply chain. A better understanding of the mechanism, relationship-dose effect and co exposure of endocrine disrupting chemicals might aid in dietary interventions for prevention of many non-communicable diseases and development of health strategies.

\section{References}

Albini, A., Rosano, C., Angelini, G., Amaro, A., Esposito, A. I., Maramotti, S.,... \&Pfeffer, U. (2014). Exogenous hormonal regulation in breast cancer cells by phytoestrogens and endocrine disruptors. Current medicinal chemistry, 21(9), 1129-1145.

Bang, D. Y., Kyung, M, Kim, M. J., Jung, B. Y., Cho M. C., Choi, S. M., Kim Y. W., Lim S. K., Lim, D. S., Won A. J., Kwack, S. J., Lee, Y., Kim H. S. \& Lee, B. M. (2012). Human Risk Assessment of Endocrine-Disrupting Chemicals Derived from Plastic Food Containers. Comprehensive Reviews in Food Science and Food Safety, 11(5): 453-470

Bell, M. R. (2014). Endocrine-disrupting actions of PCBs on brain development and social and reproductive behaviors. Current opinion in pharmacology, 19: 134-144.
Bergman, Å., Heindel, J. J., Jobling, S., Kidd, K., Zoeller, T. R., \& World Health Organization. (2013). State of the science of endocrine disrupting chemicals 2012. World Health Organization.

Burkhardt-Holm, P. (2010). Endocrine disruptors and water quality: a state-ofthe-art review. International journal of water Resources Development, 26(3): 477-493.

Charles, A. (2012). Safe food packaging and storage for better health and environment Saravanan p 2, Sathish Kumar S, Sisvanathan D 2, Silambarasan s 2. Int. J. Int sci. Inn. Tech. Sec. A, 1(5): 1-4.

Colborn, T., VomSaal, F. S., \& Soto, A. M. (1993). Developmental effects of endocrine-disrupting chemicals in wildlife and humans. Environmental health perspectives, 101(5): 378-384.

Darbre, P. D. (2019). The history of endocrinedisrupting chemicals. Current Opinion in Endocrine and Metabolic Research, 7: 26-33.

Eskenazi, B., Warner, M., Brambilla, P., Signorini, S., Ames, J., \&Mocarelli, P. (2018). The Seveso accident: A look at 40 years of health research and beyond. Environment international, 121, 71-84.

Esplugas, S., Bila, D. M., Krause, L. G. T., \& Dezotti, M. (2007). Ozonation and advanced oxidation technologies to remove endocrine disrupting chemicals (EDCs) and pharmaceuticals and personal care products (PPCPs) in water effluents. Journal of hazardous materials, 149(3), 631-642.

Fan, J. J., Wang, S., Tang, J. P., Zhao, J. L., Wang, L., Wang, J. X., \& Yang, Y. (2019). Bioaccumulation of endocrine disrupting compounds in fish with different feeding habits along the largest subtropical river, China. Environmental pollution, 247, 999-1008.

Gandolfi, F., Pocar, P., Brevini, T. A. L., \& Fischer, B. (2002). Impact of endocrine disrupters on ovarian function and embryonic development.

García-Córcoles, M. T., Cipa, M., Rodríguez- 
Gómez, R., Rivas, A., Olea-Serrano, F., Vílchez, J. L., \& Zafra-Gómez, A. (2018). Determination of bisphenols with estrogenic activity in plastic packaged baby food samples using solid-liquid extraction and clean-up with dispersive sorbents followed by gas chromatography tandem mass spectrometry analysis. Talanta, 178: 441-448.

Gill, V., Kumar, V., Singh, K., Kumar, A., \& Kim, J., J. (2019). Advanced Glycation End Products (AGEs) May Be a Striking Link Between Modern Diet and Health. Biomolecules, 9(12): 888.

GrayJr, L. E., Ostby, J., Furr, J., Wolf, C. J., Lambright, C., Parks, L.,... \& Guillette, L. (2001). Effects of environmental antiandrogens on reproductive development in experimental animals. Apmis, 109(S103), S302-S319.

Gregoraszczuk, E. L. (2002). Dioxin exposure and porcine reproductive hormonal activity. Cadernos de SaúdePública, 18(2), 453-462.

Hayes, T. B., Case, P., Chui, S., Chung, D., Haeffele, C., Haston, K.,... \&Tsui, M. (2006). Pesticide mixtures, endocrine disruption, and amphibian declines: are we underestimating the impact? Environmental health perspectives, 114(Suppl 1), 40-50.

Hoover, R. N., Hyer, M., Pfeiffer, R. M., Adam, E., Bond, B., Cheville, A. L.,... \&Troisi, R. (2011). Adverse health outcomes in women exposed in utero to diethylstilbestrol. New England Journal of Medicine, 365(14), 1304-1314.

Idrovo, A. J. (2014). Food poisoned with pesticide in Bihar, India: new disaster, same story. Occupational and environmental medicine, 71(3), 228-228.

Irshad, K., Rehman, K., Sharif, H., Tariq, M., Murtaza, G., Ibrahim, M., \&Akash, M. S. H. (2020). Bisphenol A as an EDC in Metabolic Disorders. In Endocrine Disrupting Chemicals-induced Metabolic Disorders and Treatment Strategies (pp. 251-263). Springer, Cham.

L Brevini, T. A., Zanetto, S. B., \& Cillo, F.
(2005). Effects of endocrine disruptors on developmental and reproductive functions. Current Drug Targets-Immune, Endocrine \& Metabolic Disorders, 5(1): 1-10.

Lauretta, R., Sansone, A., Sansone, M., Romanelli, F., \& Appetecchia, M. (2019). Endocrine disrupting chemicals: effects on endocrine glands. Frontiers in endocrinology, 10: 178.

McBride, W. G. (1961). Thalidomide and congenital abnormalities. Lancet, 2(1358), 90927-8.

McLachlan, J. A. (2001). Environmental signaling: what embryos and evolution teach us about endocrine disrupting chemicals. Endocrine reviews, 22(3), 319-341.

Meeker, J. D., Ferguson, K. K., \& Schecter, A. (2012). Phthalates: human exposure and related health effects. Dioxins and Health: Including Other Persistent Organic Pollutants and Endocrine Disruptors. 3rd ed. Hoboken, NJ: John Wiley and Sons, Inc, 415-443.

Metzler, M., Pfeiffer, E., \& Hildebrand, A. (2010). Zearalenone and its metabolites as endocrine disrupting chemicals. World Mycotoxin Journal, 3(4): 385-401.

Nachman, K. E., \& Smith, T. J. S. (2015). Hormone Use in Food Animal Production: Assessing Potential Dietary Exposures and Breast Cancer Risk. CurrEnvir Health Rpt 2, 1-14.

Nash, J. P., Kime, D. E., Van der Ven, L. T., Wester, P. W., Brion, F., Maack, G.,... \& Tyler, C. R. (2004). Long-term exposure to environmental concentrations of the pharmaceutical ethynylestradiol causes reproductive failure in fish. Environmental health perspectives, 112(17), 1725-1733.

Nicolopoulou-Stamati, P., Hens, L., \& Sasco, A. J. (2015). Cosmetics as endocrine disruptors: are they a health risk?. Reviews in Endocrine and Metabolic Disorders, 16(4), 373-383.

Papalou, O., Kandaraki, E. A., Papadakis, G., \& Diamanti-Kandarakis, E. (2019). 
Endocrine disrupting chemicals: an occult mediator of metabolic disease. Frontiers in endocrinology, 10: 112.

Patrick, S. M., Bornman, M. S., Joubert, A. M., Pitts, N., Naidoo, V., \& De Jager, C. (2016). Effects of environmental endocrine disruptors, including insecticides used for malaria vector control on reproductive parameters of male rats. Reproductive Toxicology, 61, 19-27.

Pilsakova, L., Riecanský, I., \& Jagla, F. (2010). The physiological actions of isoflavone phytoestrogens. Physiological Research, 59(5), 651.

Priyam, A., Singh, P. P., \& Gehlout, S. (2018). Role of endocrine-disrupting engineered nanomaterials in the pathogenesis of type 2 diabetes mellitus. Frontiers in endocrinology, 9: 704.

Purnomo, A. S., Mori, T., Kamei, I., \& Kondo, R. (2011). Basic studies and applications on bioremediation of DDT: a review. International Biodeterioration \& Biodegradation, 65(7): 921-930.

Rao E. S., Rizwana, Lalmuanpuia, C., Aparajita G. and Prateek K. (2021) Food Additives and Hypersensitivity: A Review. Int.J.Curr.Microbiol.App.Sci 10(02): 1697-1717.

Ravichandran, G., Lakshmanan, D. K., Raju, K., Elangovan, A., Nambirajan, G., Devanesan, A. A., \& Thilagar, S. (2019). Food advanced glycation end products as potential endocrine disruptors: An emerging threat to contemporary and future generation. Environment international, 123: 486-500.

Rietjens, I. M., Louisse, J., \& Beekmann, K. (2017). The potential health effects of dietary phytoestrogens. British journal of pharmacology, 174(11), 1263-1280.

Rotondo, E., \& Chiarelli, F. (2020). EndocrineDisrupting Chemicals and Insulin Resistance in Children. Biomedicines, 8(6): 137.

Schantz, S. L., \&Widholm, J. J. (2001). Cognitive effects of endocrine-disrupting chemicals in animals. Environmental health perspectives, 109(12), 1197-1206.

Siegrist, H., Joss, A., Ternes, T., \& Oehlmann, J. (2005). Fate of EDCs in wastewater treatment and EU perspective on EDC regulation. Proc Water Environ Fed, 3142-65.

Söffker, M., \& Tyler, C. R. (2012). Endocrine disrupting chemicals and sexual behaviors in fish-a critical review on effects and possible consequences. Critical reviews in toxicology, 42(8), 653668.

Soto, A. M., \& Sonnenschein, C. (2015). DDT, endocrine disruption and breast cancer. Nature Reviews Endocrinology, 11(9): 507-508.

Stevens J F, Page J E (2004). Xanthohumol and related prenylflavonoids from hops and beer: to your good health! Phytochemistry 65: 1317-1330.

Waye, A., \& Trudeau, V. L. (2011). Neuroendocrine disruption: more than hormones are upset. Journal of Toxicology and Environmental Health, Part B, 14(5-7), 270-291.

Wirbisky, S. E., Weber, G. J., Sepúlveda, M. S., Lin, T. L., Jannasch, A. S., \& Freeman, J. L. (2016). An embryonic atrazine exposure results in reproductive dysfunction in adult zebrafish and morphological alterations in their offspring. Scientific reports, 6(1), 1-13.

\section{How to cite this article:}

Eram S. Rao, C. Lalmuanpuia, Rizwana, Utkarsh Singh and Divyanshu Prajapat. 2021. Endocrine Disruptors in Food Chain. Int.J.Curr.Microbiol.App.Sci. 10(06): 175-187. doi: https://doi.org/10.20546/ijcmas.2021.1006.019 